\title{
SOLVING THE STUDENTS' PROBLEMS IN WRITING ARGUMENTATIVE ESSAY THROUGH COLLABORATIVE WRITING STRATEGY
}

\author{
M. Fadhly Farhy Abbas \\ English Education Department, Faculty of Teacher Training and Education, Universitas Lancang \\ Kuning Pekanbaru, Indonesia \\ E-mail: fadhly@unilak.ac.id
}

Herdi

English Education Department, Faculty of Teacher Training and Education, Universitas Lancang Kuning Pekanbaru, Indonesia

E-mail: herdi@unilak.ac.id

APA Citation: Abbas, M. F. F., \& Herdi, H. (2018). Solving the students' problems in writing argumentative essay through collaborative writing strategy. English Review: Journal of English Education, 7(1), 105-114. doi: 10.25134/erjee.v7i1.1499.

\begin{abstract}
This research is based on the students' problems in writing argumentative essay, especially in developing and organizing ideas, using good grammar and diction, and applying correct writing mechanics, such as the use of capital letter, spelling, and punctuation. The purpose of this research is to solve the students' problems in writing argumentative essay through collaborative writing strategy. The design employed in this research was classroom action research. The participants involved in this research were 23 students of English Education Department, Faculty of Teacher Training and Education, University of Lancang Kuning Pekanbaru, Indonesia. The instruments used in this research were writing test, field note, observation checklist, and interview. Based on the result of the test, the students' score had reached the criteria of success set, and it was significantly improved from the result before the research conducted. The mean score of the mid-term test was 54.9, and the mean score of the cycle test was 74.3. In addition, based on the data gained from the field note, observation checklist, and interview, it was found that the students were active, creative, and enjoy the learning process. In conclusion, the use of collaborative writing strategy can solve the students' problems in writing argumentative essay as well.
\end{abstract}

Keywords: writing skill; writing aspects; argumentative essay; collaborative writing strategy; classroom action research.

\section{INTRODUCTION}

Basically, writing is an activity of expressing, developing, and organizing ideas into written form. The more ideas the writers have, the better writing product will be. However, to express, develop, and organize ideas into written form is not easy. There are two aspects in writing that must be considered by the writers. First, writing process, such as pre-writing, drafting, revising, editing, and publishing (Fachrurrazy, 2011). Second, micro and macro skills of writing, such as the ability to use word diction, grammar, and writing mechanics including the use of capital letter, spelling, and punctuation (Brown, 2015).

In accordance with the above statement, both aspects of writing are still difficult to be applied by the students of English Education Department, Faculty of Teacher Training and Education, University of Lancang Kuning especially for the students who are already studying academic writing course. In Academic Writing course, the students are targeted to be able to write essay in the form of argumentative essay.

Argumentative essay is a scientific paper that contains arguments, explanations, 


\section{Fadhly Farhy Abbas \& Herdi}

Solving the students' problems in writing argumentative essay through collaborative writing strategy

proofs, or reasons. Generally, in an argumentative essay, there is an objective review or information followed by examples, analogies, and cause and effect relationship (Housden, 2013). Further, Bowell and Kemp in Ibrahim, Eljack, and Elhassan (2015) explain that the argument displayed with good and right reasons is an attempt to influence, invite someone or lead opinions to certain things. Besides, argumentative essay can also contain arguments about pro (supporting ideas) and contra (conflicting ideas) on the issues or topics being discussed (Boun, 2009).

Based on the teaching experience, the researchers found various problems in writing argumentative essays faced by the students. The students felt difficult when developing and organizing ideas, using correct grammar and word choices, and applying correct writing mechanics, such as the use of capital letter, spelling, and punctuation. The difficulty faced by the students in writing argumentative essays can be seen from the results of the mid-term test in which the obtained score was 54.9, and it was categorized into poor level ability.

Based on the above problems, the researchers want to apply a learning strategy to solve or overcome the problems faced by students in writing argumentative essay. The strategy is Collaborative Writing. This strategy requires students to write together in pair consisting of helper and writer. The writing activity starts from planning, writing the draft, revising, and editing an article (Abbas, Fachrurrazy, \& Wahjudi, 2013). This strategy is expected to help students in solving the problems they face in writing argumentative essay.

There are several steps or procedures that must be taken in implementing Collaborative Writing strategy in learning process (Zuhri, 2009). The first step is idea generation. In this step, the students are asked to generate as many as ideas based on the topic assigned or picture provided by the lecturer. The second step is drafting. At this step, the students are asked to write a draft of the topic assigned which has been given based on ideas that have been generated previously. The third step is revising and editing. At this step, the helper is asked to revise the draft that has been written by the writer, and the writer rewrites the revised ideas to become a well-written article. Then, the helper and writer edit the revised draft simultaneously. The editing process focuses on the use of grammar, vocabulary or mechanics of writing. The last step is publishing. In this step, the students display the results of their writing in front of the class. Then, the lecturer asks other students to check the results of the writing to get feedback. After that, the lecturer gives an assessment towards the students' work.

In accordance with the above description, aim of this research is to solve the students' problems in writing argumentative essay through collaborative writing by considering these two things, namely; (1) measuring the students' improvement in writing argumentative essay, and (2) identifying the factors that influence the students' improvement in writing argumentative essay.

\section{METHOD}

The research design used in this study was classroom action research. In this research, the researchers worked collaboratively with other English lecturers as the research collaborator. This research consisted of 4 steps or procedures, namely plan, action, observation, and reflection. This steps was called as the research cycle.

The participants involved in this study were the 23 students of English Education Department, Faculty of Teacher Training and Education, University of Lancang Kuning Pekanbaru, Indonesia in the $4^{\text {th }}$ semester in 2017/2018 Academic Year who took academic writing course. The students were chosen because of their low ability in writing argumentative essay.

The data were collected by using instruments, such as writing test, field note, observation checklist, and interview. After collecting the data, the researchers assessed and analyzed the students' test results using 
ENGLISH REVIEW: Journal of English Education Volume 7, Issue 1, December 2018
p-ISSN 2301-7554, e-ISSN 2541-3643

https://journal.uniku.ac.id/index.php/ERJEE

the scoring rubric and final score category

(Adapted from Abbas, 2015, 2018). provided in Table 1 and Table 2 below

Table 1. The scoring rubric for argumentative essay assessment

\begin{tabular}{|c|c|c|c|}
\hline Aspects & Criteria & Scores & Category \\
\hline & Thorough development of topic & 20 & Very Good \\
\hline Content: & Relevant to topic but lacks detail & 15 & Good \\
\hline \multirow[t]{3}{*}{ topic development } & Inadequate development of topic & 10 & Fair \\
\hline & Does not show knowledge of topic & 5 & Poor \\
\hline & $\begin{array}{l}\text { Organize paragraph well and show good coherence } \\
\text { and chronological order }\end{array}$ & 30 & Very Good \\
\hline \multirow{4}{*}{$\begin{array}{l}\text { Organization: } \\
\text { unity, coherence, } \\
\text { logical order }\end{array}$} & Loosely organized but ideas stand out & 25 & Good \\
\hline & Incoherent ideas and lacks logical sequencing & 20 & Fair \\
\hline & $\begin{array}{l}\text { Does not organize paragraph well and does not show } \\
\text { good coherence and chronological order }\end{array}$ & 15 & Poor \\
\hline & $\begin{array}{l}\text { Employ accurate and effective choice of } \\
\text { words/diction }\end{array}$ & 20 & Very Good \\
\hline \multirow{4}{*}{$\begin{array}{l}\text { Vocabulary: } \\
\text { word choice/ } \\
\text { diction }\end{array}$} & Employ accurate diction, but not effective & 15 & Good \\
\hline & $\begin{array}{l}\text { Employ lacks accuracy of diction, but meaning not } \\
\text { obscured }\end{array}$ & 10 & Fair \\
\hline & $\begin{array}{l}\text { Errors in applying diction or word form, and meaning } \\
\text { obscured }\end{array}$ & 5 & Poor \\
\hline & $\begin{array}{l}\text { Use correct grammar (pronouns, subject-verb } \\
\text { agreement, etc) }\end{array}$ & 20 & Very Good \\
\hline \multirow{4}{*}{$\begin{array}{l}\text { Grammar: } \\
\text { sentence structure/ } \\
\text { construction }\end{array}$} & $\begin{array}{l}\text { Several errors of tense, pronouns, subject-verb } \\
\text { agreement, etc, but meaning not obscured }\end{array}$ & 15 & Good \\
\hline & $\begin{array}{l}\text { Major errors of tense, pronouns, subject-verb } \\
\text { agreement, etc, and meaning obscured }\end{array}$ & 10 & Fair \\
\hline & $\begin{array}{l}\text { No mastery of sentence construction and dominated } \\
\text { by errors }\end{array}$ & 5 & Poor \\
\hline & Very little errors of mechanics & 10 & Very Good \\
\hline \multirow{3}{*}{$\begin{array}{l}\text { Mechanics: } \\
\text { spelling, } \\
\text { punctuation, and } \\
\text { capitalization } \\
\end{array}$} & Few errors of mechanics, but meaning not obscured & 9 & Good \\
\hline & Many errors of mechanics, and meaning obscured & 7 & Fair \\
\hline & Dominated by errors of mechanics & 5 & Poor \\
\hline
\end{tabular}

Table 2. The final score category

\begin{tabular}{cc}
\hline Range of Final Scores & Category \\
\hline $86-100$ & Very Good \\
$71-85$ & Good \\
$56-70$ & Fair \\
$10-55$ & Poor \\
\hline
\end{tabular}

\section{RESULTS AND DISCUSSION}

Based on the results of field notes, observation checklists, and interviews, the researchers found information that the learning process in the classroom run well. Based on the results of field notes, it was found that the students were very active during the learning process through collaborative writing strategy.

Based on the results of the observation checklist, it was found that every step of collaborative writing strategy was done well by the students. Morover, based on the interview, it was found that the students felt active, creative, and enjoyable during the learning process. It was indicated that there were other factors that influence the students' ability in writing argumentative essay besides the result of the test.

In relation to the above statement, the findings from each meeting of teaching and learning process can be described as follows. At the first meeting, the learning process begun with the introduction. Before the 


\section{Fadhly Farhy Abbas \& Herdi}

Solving the students' problems in writing argumentative essay through collaborative writing strategy

introduction activity, the researchers conducted a warming up activity in the form of recalling what students understood about the argumentative essay and how to write it down. This was done to make sure whether the students understood about argumentative essay or not.

After the recalling process done, the researchers provided an example of an argumentative essay to students to be analyzed or discussed together. Then, the researchers asked the students to look for the main idea of the essay, understood the development of the idea, and determined the language characteristics used, such as tenses and other aspects of writing. Then, the researchers asked the students to exchange their worksheets with their friends to get feedback.

After the above process was completed, the researchers introduced a teaching strategy called Collaborative Writing strategy and its implementation in the teaching and learning process. After that, the researchers asked the students to make a group in pairs and determined one student as a writer and other students as helper. Furthermore, the researchers provided a topic about Education to be written by the students into an Argumentative essay. Then, the researchers asked the students to find many ideas that should be written into the initial draft. Then, the researchers assigned the students to work at home.

At the second meeting, the students were asked to submit the assignment given at the first meeting (generating idea and drafting). Then, the researchers gave comments on the students' work both in spoken and written comments. After giving comments on students' work, the researchers assigned the students to revise and edit again the drafts that have been made. The revising and editing process were focused on the use of appropriate language features, correct choice of words, and correct use of writing mechanics, such as spelling, punctuation, and capital letters.

At the third meeting, the learning process focused on publishing stage. At this stage, the students were asked to display their written work in front of the class. This was done so that all students in the class could understand and could give feedback on their friends' work. At this meeting, the students got good input in learning to write Argumentative essay.

At the fourth meeting, the researchers gave an assessment toward the students' work in writing argumentative essay. The assessment focused on aspects of content (topic development), Organization (structure of paragraph), vocabulary (diction/word choice), grammar (sentence sturcture), and mechanics (writing mechanism). At this meeting, the researchers assessed in terms of content that can be seen from the topics development capabilities at the Argumentative Essay writing. Then, the researchers assessed in terms of organization which can be seen from the paragraph structure in the writing. Then, the researchers assessed in terms of vocabulary that can be seen from the students' ability in word selection in the argumentative essay writing. Furthermore, the researchers assessed in terms of grammar that can be seen from the good grammatical abilities of the argumentative essay writing. Finally, the researchers assessed in terms of mechanics that can be seen from the ability of the writing mechanism in the argumentative essay.

At the fifth meeting, the cycle test was administered. Therefore, the researchers carried out the stage of giving a writing test to students to measure the extent of student achievement in the process of writing argumentative essays. After the test, the researchers assessed the students' work and the results of the assessment can be seen in Table 3.

\begin{tabular}{|c|c|c|}
\hline Test & Score & Category \\
\hline Cycle & 74.3 & Good \\
\hline
\end{tabular}

Based on the result of the test cycle provided in Table 3, it can bee seen that the result of test cycle was in good category. It means that this score was in good level of 
ENGLISH REVIEW: Journal of English Education Volume 7, Issue 1, December 2018

ability. The score achieved by the students was 74.3. In relation to the result of the test cycle, the comparison of the result of the test cycle and mid term test result can clearly be seen at Table 4.

Table 4. The result of the writing tests

\begin{tabular}{cccc}
\hline No & Test & Score & Category \\
\hline 1. & Mid term & 54.9 & Poor \\
2. & Cycle & 74.3 & Good \\
\hline
\end{tabular}

Based on the information provided in Table 4, it can be seen that the average score of the students mid term test was 54.9 and it was categorized into poor level of ability. However, after conducting the research for 5 meetings ( 1 cycle), the average score of the students increased significantly. The mean score of the students in this test was 74.3, and it was categorized into good level of ability.

Referring to the results of the tests showed on the Table 3 and Table 4, the results of the writing tests obtained by students can be described in Diagram 1 .

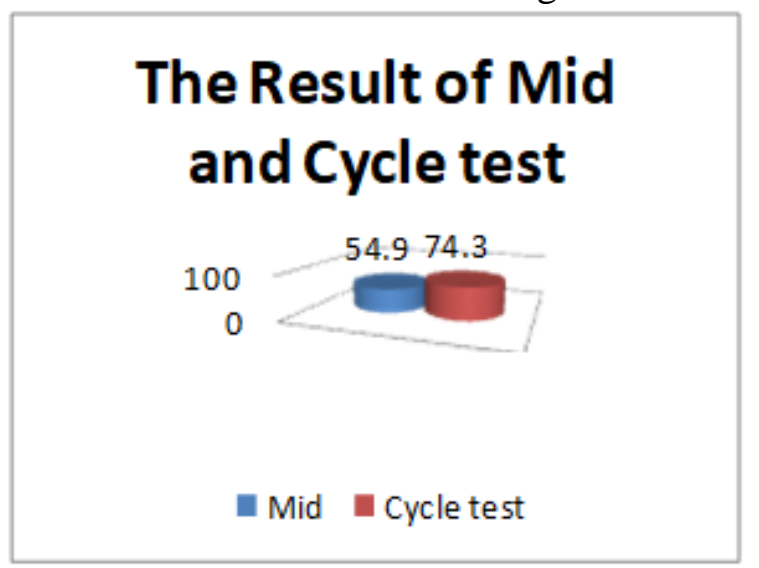

Diagram 1. Comparison of mid results and cycle test

Based on Diagram 1, it can be clearly seen that the score obtained in the mid term test was lower than the score achived in the cycle test. The score for mid term test was
p-ISSN 2301-7554, e-ISSN 2541-3643

https://journal.uniku.ac.id/index.php/ERJEE

54.9 and the score for the cycle test was 74.3.

In relation to the the results above, in the mid term test, there is no students who got the score above the standard score. The score that the students obtained was the score that was in fair and poor score category. Furthermore, from 23 students who were participated in this research, 12 students were achieved fair score category, and 11 students got the poor score category.

In the cycle test, it was found that the overall score of students was in good category. From 23 students involved in this research, there were 5 people who got very good category, 12 people got good category, and 6 students got fair score category. Furthermore, the details can be seen in Table 5.

Table 5. The comparison of participants amount and the score categories achieved

\begin{tabular}{cccl}
\hline No & Tests & $\begin{array}{c}\text { Amount of } \\
\text { Participants }\end{array}$ & $\begin{array}{c}\text { Score } \\
\text { Category }\end{array}$ \\
\hline 1. & Mid & 12 & Fair \\
& term & 11 & Poor \\
2. & Cycle & 5 & Very Good \\
& & 12 & Good \\
& & 6 & Fair \\
\hline
\end{tabular}

Based on the information provided in Table 5, it can be seen that there was an improvement from the results of the Midterm test. It showed that collaborative writing strategy was effective and beneficial in improving students' writing skill. It means that the use of collaborative writing can improve the students' writing skill.

In accordance with the above explanations, the five aspects of writing (content, organization, vocabulary, grammar, and mechanics) became the focus of writing assessment in this research. Moreover, the scores obtained for every single aspect of writing can be seen in Diagram 2. 


\title{
The Writing Aspects
}

\author{
= Content $\quad$ Organization = Vocabulary \\ - Grammar = Mechanics
}

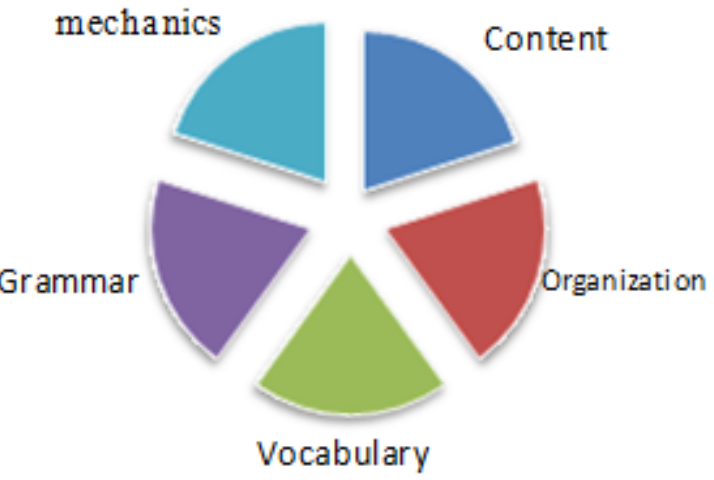

Diagram 2. The writing aspects

Diagram 2 shows the criteria assessed were the development of a deep topic (thorough development of topic) in the category of very good, related to the topic but not detailed in the explanation (relevant to topic but lacks details) with good category, inadequate development of topic in the fair category, and does not show a scientific understanding of the topic (do not show knowledge of topic) with a poor category.

First, in the aspect of content in the cycle test, the score obtained was 16.5 and it was categorized into good score category. There was no problem in developing the topic of the assigned task. Second, in the aspect of organization, the score was 21.7 and it was in the fair category. According to the scoring rubric, the criteria assessed was to compile paragraphs well and show good chronological coherence and arrangement (organize paragraph well and show good coherence and chronological orders) in the category of very good, poorly structured which was very good (loosely organized but ideas stand out) with good categories, there was no idea or coherence and incoherent ideas and lack of logical sequencing in the fair category, and paragraphs were not well organized and did not show good coherence and chronological order (did not organize paragraph well and did not show good coherence and chronological order) with a poor category.

Third, for the aspect of vocabulary, the score ontained was 15 and it was in good category. The criteria assessed were about the ability in using correct word choice in the category of very good, using accurate but ineffective diction (employ accurate diction, but not effective) with good category, using diction or words that were less precise but the meaning of the word was not too vague (employ lacks accuracy of dictionaries, but meaning not obscured) in the fair category, there was an error in the selection of diction or word form and meaning of the word was unclear (errors in applying diction or word form, and meaning obscured) with the poor category.

Fourth, for the grammar aspect, the score ontained was 13.5 and it was in the fair category. The criteria assessed were about the ability in using good grammar, such as pronouns, subject and verb agreement, and many others. It covered; 1) the use of correct grammar, pronouns, subject-verb agreement, and so on, with very good category, 2) there were some errors in the use of tenses, pronoun, subject-verb agreement and so on, 
ENGLISH REVIEW: Journal of English Education Volume 7, Issue 1, December 2018

but the meaning was not vague (several errors of tense, pronouns, subject-verb agreement, but meaning not obscured) with good category, 3) there were many errors in the use of tenses, pronouns, the suitability of the subject and verb and so on and their meaning were vague (major errors of tense, pronouns, subject-verb agreement, and so on, and meaning obscured) in the fair category, and 4) not mastering the sentence structure and dominated by errors (no mastery of sentence structure and dominated by errors) in the poor category.

Fifth, in the mechanics aspect, the score obtained was 7.6 and it was categorized into fair category. The criteria assessed were; 1)
p-ISSN 2301-7554, e-ISSN 2541-3643

https://journal.uniku.ac.id/index.php/ERJEE

very few errors in the writing mechanism (very little errors of mechanics) with very good category, 2) some errors that occured in the writing mechanics but the meaning was not vague (few errors of mechanics, but meaning not obscured) with good category, 3) many errors occured in the writing mechanics and the meaning was fuzzy (many errors of mechanics, and meaning obscured) with the fair category, and 4) dominated by errors in the writing mechanics with poor category. In other words, if the overall average score was obtained then the score would be in good level ability. The details is presented in Table 6.

Table 6. The students' writing test results per writing indicator

\begin{tabular}{cccccc}
\hline \multirow{2}{*}{ Tests } & \multicolumn{5}{c}{ Aspects } \\
\cline { 2 - 6 } & Content & Organization & Vocabulary & Grammar & Mechanics \\
\hline Mid term & 12.6 (fair) & 13.2 (poor) & 11.9 (fair) & 9.8 (poor) & 7.2 (fair) \\
Cycle & 16.5 (good) & 21.7 (fair) & 15 (good) & 13.5 (fair) & 7.6 (fair) \\
\hline
\end{tabular}

In accordance with the information provided in Table 6 , it can be seen that the scores obtained by the students in the midterm test were lower than the scores obtained in the cycle test. The score for content in the mid-term test was 12.6 and it was improved in the test cycle to 16.5. The score for organization in mid-term test was 13.2 and improved in the test cycle to 21.7. The score for vocabulary in mid-term was 11.9 , and it improved in the test cycle to 15 . For grammar aspect, the score in mid-term was 9.8, and in the test cycle was 13.5. At last, the score for mechanics in mid-term test was 7.2 and it was improved to 7.6 in the test cycle. Furthermore, the clear information about the comparison of the writing test can be seen in Diagram 3.

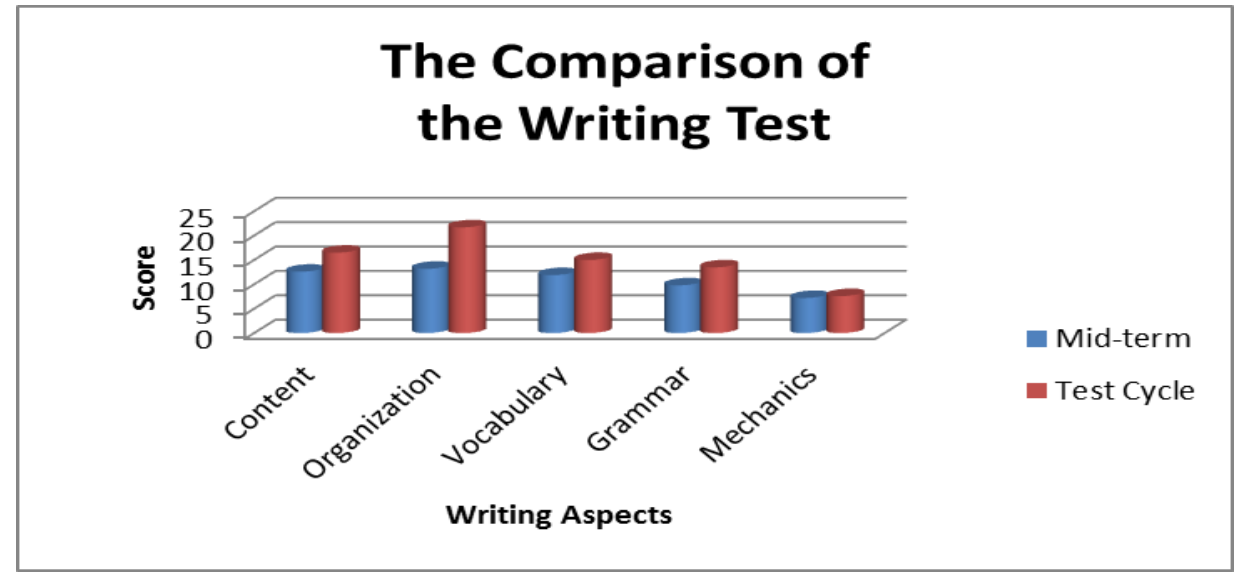

Diagram 3. Significant comparison between mid-term results and cycle test results 


\section{Fadhly Farhy Abbas \& Herdi}

Solving the students' problems in writing argumentative essay through collaborative writing strategy

In line with the information in Table 6 mid-term test can also be seen in Diagram 4. and Diagram 3, the results of the students'

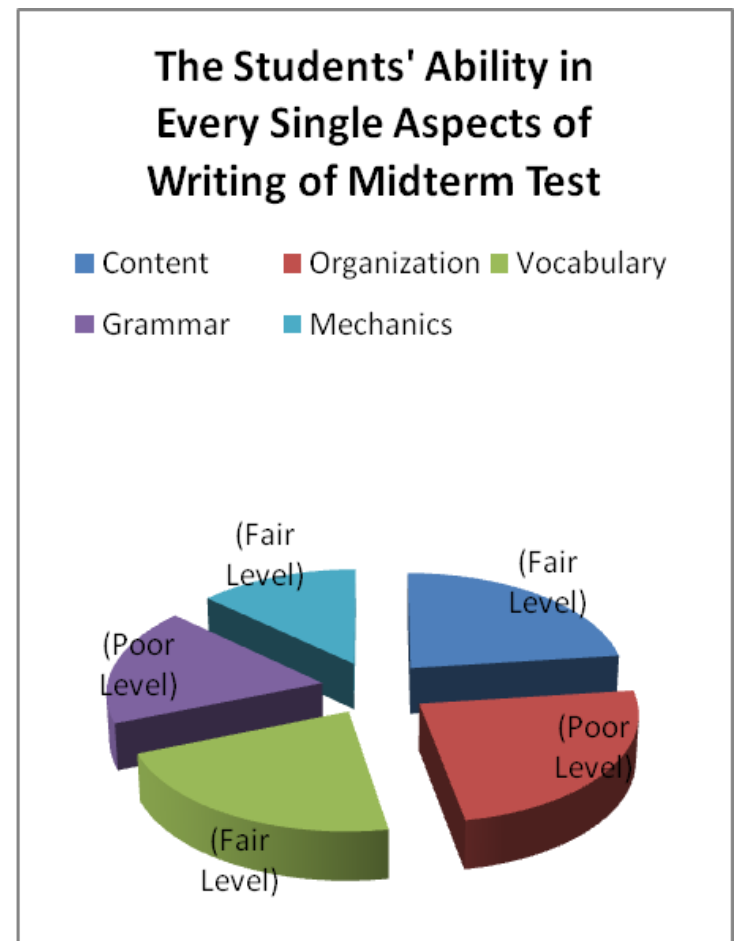

Diagram 4. The students' mid-term test results per assessment aspect

The Diagrams show the comparison of students' test results in writing argumentative essay. It can be clearly seen that the students' achievement improves from mid term results to the cycle test. In other words, the students scores in the cycle test were higher than the mid term scores. It means that there has been an improvement in the students' ability in writing Argumentative essay after conducting the research using Collaborative Writing strategy. Thus, it can be stated that the implementation of the Collaborative Writing strategy in learning Argumentative essay writing could help students in improving their writing skill.

Based on the results obtained from each research instrument, it can be stated that the ability of the $4^{\text {th }}$ semester students of English Education Department, Faculty of Teacher Training and Education, University of Lancang Kuning in Academic Year 2017/2018 in writing argumentative essay were categorized into good level of ability. Then, the researchers decided to complete the research until cycle 1 . It means that the research was not continued to the next cycle. It was because there was a match between achievement and the criteria of success set in this research. The scores achieved by the students were higher than the minimum passing score.

In line with the previous explanation, it can be stated that good ability of the students in writing argumentative essays was basically influenced by the students' good ability in applying the Collaborative Writing strategy. This research result was in line with previous research conducted by Abbas, Fachrurrazy, \& Wahjudi (2013), Zuhri (2009), Wahyuni (2017), Soraya (2016), and Lestari, Setyowati, Sukmawan, and Latief (2017) about the implementation of collaborative writing strategy in improving the students' writing skill. Based on the results of this research, it was proven that the implementation of the collaborative writing strategy in the learning process could improve the students' skill in writing. 
ENGLISH REVIEW: Journal of English Education Volume 7, Issue 1, December 2018

In accordance with the above statement, the research conducted by Sarmidi (2009) and Isnawati (2009) were also related to the results of this research. This was because each stage of writing process was correctly applied by the students in the learning process. Therefore, this activity let the students to write smoothly and correctly. In other word, this process let the students to improve their writing skill, especially in writing argumentative essay.

Pertaining to the above explanation, although the writing skill of the students in writing argumentative essays was good, there were two things became the weaknesses in this research. First, the limited time in the learning process was a bit of a constraint in this research. 90 minutes or 2 credits for writing class was too short and not enough. So, it was recommended that the time allocation for writing lectures to be added at least 3 credits. Second, not all students achieved good score category in this research. It was found that 6 students who obtained score below the passing score, and the score was in the fair and poor category. Thus, the researchers suggest the 6 students to practice writing harder and more actively so that their writing skill can be improved. The more often the students practice writing, the better writing skill would be.

\section{CONCLUSION}

Based on the analysis, there are some points that need to be highlighted. First, in the aspect of content, the score obtained is $\mathbf{1 6 . 5}$ and it is in the good category. From the rubric, this category can be seen from the criteria, such as; develop ideas relevant to the topic but less detail so that they can be categorized into good. Second, in the aspect of organization, the score achieved is 21.7 and it is in the fair category. Based on the rubric, the criteria for students in this study is there is no coherence on paragraph composition and ideas are also less logical in order (incoherent ideas and lack of logical sequencing) so that they can be categorized into fair level. Third, for the aspect of
p-ISSN 2301-7554, e-ISSN 2541-3643

https://journal.uniku.ac.id/index.php/ERJEE

vocabulary, the score is 15 and it is categorized into good. The criteria is that students use accurate but ineffective diction (employ accurate diction, but not effective) so that they can be categorized into good category. Fourth, in the grammar aspect, the score obtained is 13.5 and the category is fair. The criteria is that there are many errors in the use of tenses, pronouns, suitability of subjects and verbs and so on and their meaning was vague (major errors of tense, pronouns, subject-verb agreement, and so on, and meaning obscured) so that it can be categorized into fair level. In the fifth aspect, the score obtained for mechanics is 7.6 and it is in the fair category. The criteria is that there are many errors in the writing mechanism and the meaning is unclear (many errors of mechanics, and meaning obscured), dominated by errors in the writing mechanism so that it is categorized into poor level. In addition, the mean score obtained by the students is 74.3 and it is categorized into good level of ability.

In relation to the above explanation, it can be concluded that the use of collaborative writing strategy can solve the students' problems in writing argumentative essay. In other word, the implementation of collaborative writing strategy in the teaching of argumentative essay writing can improve the students' writing skill. Moreover, this improvement is supported by two points, namely; 1) The mean score of the students is 74.3 and it is categorized into good level of ability, and 2) The factors that influence the students' improvement in writing argumentative essay are; the students are active, creative, and enjoy the learning process by using collaborative writing strategy.

\section{ACKNOWLEDGEMENT}

In this part, the researchers need to express many thanks to the persons who helped in the research. First, the researchers would like to say thank to Ministry of Research, Technology, and Higher Education of Republic of Indonesia (KEMRISTEKDIKTI RI) who gave financial support. Second, the 


\section{Fadhly Farhy Abbas \& Herdi}

Solving the students' problems in writing argumentative essay through collaborative writing strategy

researchers also would like to say thank to LPPM and team of Universitas Lancang Kuning Pekanbaru, Indonesia who provided good service for the researchers during the research. At last, the appreciation goes to the research assistants, head of English Education Department, and head of UP2M of FKIP UNILAK who supported totally during the research.

\section{REFERENCES}

Abbas, M. F. F. (2018). Assessing EFL students' ability in developing idea to organize academic essay. IOP Conference Series: Earth and Environmental Science 175(1), 012-074.

Abbas, M. F. F. (2015). Analysis of students' ability in writing a research proposal. ELT-Lectura, 2(2).

Abbas, M., Fachrurrazy, F., \& Wahjudi, A. (2013). Applying collaborative writing process strategy to improve students' ability in writing a narrative text. disertasi dan tesis Program Pascasarjana UM.

Boun, E. (2009). Argumentative essay. Retrieved June 6, 2017, from www.buowl.boun edu.

Brown, H. D. (2015). Teaching by principles: An interactive approach to language pedagogy $\left(5^{\text {th }}\right.$ ed.). White Plains, New York: Pearson Education.

Fachrurrazy. (2011). Teaching English as a foreign language for teachers in Indonesia. Malang: Universitas Negeri Malang Press.

Housden, E. (2013). Senior text types: A writing guide for students. Farrbooks: Quendsland.

Ibrahim, M. E. E., Eljack, N. S. A., \& Elhassan, I. B. M. (2015). To what extent can argumentative essay writing help develop leaners' critical thinking. SUST Journal of Humanities, 16(4).

Isnawati, U.M. (2009). Improving the writing ability of the 11th grade students of MA Hasyim Asy'ari Kembangbahu Lamongan through the implementation of the scaffolding strategy. Unpublished Thesis. Malang: Universitas Negeri Malang.

Lestari, Setyowati, S., Sukmawan, \& Latief, M. A. (2017). Solving the students' problems in writing argumentative essay through the provision of planning. A Journal of Culture, English Language, Teaching \& Literature, 17(1), 87102.

Sarmidi. (2009). The use of directed writing activity strategy to enhance the students' skill in writing recount texts at MTSN Margoyoso-Pati. Unpublished master's thesis. Malang: Universitas Negeri Malang.

Soraya, K. (2016). The effectiveness of collaborative writing strategy (CWS) in writing lesson regarded to the students' creativity. Lingua Cultura, 10(2), 63-67.

Wahyuni, S. (2017). Improving students ability in writing through collaborative writing strategy at the islamic junior high school Muhammadiyah 01 Medan. Unpublished thesis. Medan: Department of English Education Faculty of Tarbiyah and Teacher Training State Islamic University of North Sumatera. Retrieved from http://repository.uinsu.ac.id/2643/1/COVER\%20 SKRIPSI\%20CIWA.pdf.

Zuhri, S. (2009). Improving the ability in writing a recount text of the first year-students of MAN Wlingi through collaborative writing strategy. Unpublished master's Thesis. Malang: Universitas Negeri Malang. 